\title{
CHANGES IN THE CONTENT OF TOTAL NITROGEN, PHOSPHORUS AND POTASSIUM IN POTATO TUBERS UNDER THE INFLUENCE OF THE USE OF HERBICIDES
}

\author{
Marek Gugała' ${ }^{1}$ Anna Sikorska', Krystyna Zarzecka' ${ }^{1}$ Krzysztof Kapela' \\ 1 Siedlce University of Natural Sciences and Humanities, Prusa St. 14, 08-110 Siedlce, Poland, e-mail: gugala@ \\ uph.edu.pl
}

Received: 2015.09.11

Accepted: 2015.10.06

Published: 2015.11.10

\begin{abstract}
A field experiment was conducted in the years 2005-2007 in RSD in Zawady belonging to the University of Natural Sciences and Humanities in Siedlce. The experiment was set in the split - plot system in three repetitions. The investigated factors were: I - edible potato varieties - Irga and Balbina. II - four ways of mechanical cultivation - three using herbicides: Plateen 41.5 WG, Racer 250 EC, Sencor $70 \mathrm{WG}$ and without herbicides (control object). The aim of the studies was to determine the effect of herbicides on the content of total nitrogen, phosphorus and potassium in tubers of two varieties of the edible potato. The mechanical-chemical care applied in the experiment contributed to the increase in the content of total nitrogen and lowering of phosphorus and potassium compared to the only mechanical care. The Irga variety was characterised by a significantly higher content of total nitrogen (average $-15.84 \mathrm{~g} \cdot \mathrm{kg}^{-1}$ ) and phosphorus (average $-3.526 \mathrm{~g} \cdot \mathrm{kg}^{-1}$ ), while the Balbina variety had a higher content of potassium - average $25.28 \mathrm{~g} \cdot \mathrm{kg}^{-1}$. Climatic conditions in particular growing seasons had a significant impact on the content of total nitrogen and potassium in edible potato tubers.
\end{abstract}

Keywords: potato, methods of care, herbicides, total nitrogen, phosphorus, potassium

\section{INTRODUCTION}

One of the most important plants in human nutrition is the potato. Potato tubers are an excellent source of carbohydrates, vitamins and minerals. White et al. [2009] stated that that the consumption of one medium-sized potato with a weight of $200 \mathrm{~g}$ provides 17 up to $18 \%$ of the daily requirement of potassium and phosphorus. The proper nutrition is one of the key factors affecting the growth and development of organisms. An important role is played by minerals, which serve not only as building materials, but also regulators determining the course of metabolic processes [Stefańska et al. 2003].

The chemical composition of potato tubers is conditioned by genetics of the variety, and the mineral content in the tubers may be subject to change due to weather condition prevailing during the growing season and agronomic factors, in- cluding herbicides [Gugała et al. 2009, Klikocka 2001]. The aim of the study was to determine the effect of herbicides on the content of total nitrogen, phosphorus and potassium in tubers of two varieties of the edible potato.

\section{MATERIAL AND METHODS}

The field experiment was conducted in the years 2005-2007 in the Agricultural Experimental Station in Zawady belonging to the University of Natural Sciences and Humanities in Siedlce. The experiment was set in the split-plot system as two-factor in three repetitions.

I) factor - two varieties of a potato: Irga and Balbina,

II) factor - four ways of care:

- mechanical care, i.e., until the emergence of double or triple soiling connected with har- 
rowing, after the emergence before the close of the rows soiling - the control object,

- mechanical-chemical care, i.e., to the emergence of double soiling connected with harrowing, and just before the emergence soiling + herbicide Plateen 41,5 WG (flufenacet $24 \%+$ metribuzin $17.5 \%$ ) at a dose of $2.0 \mathrm{~kg} h a^{-1}$,

- mechanical-chemical care, i.e., single soiling and up to 10 days after planting potatoes spraying with herbicide Racer 250 EC (flurochloridon $250 \mathrm{~g}$ ) at a dose of $3.0 \mathrm{dm}^{3} \mathrm{ha}^{-1}$,

- mechanical-chemical care, i.e., to the emergence double soiling connected with harrowing, and just before the emergence of soiling + herbicide Sencor 70 WG (metribuzin $70 \%$ ) at a dose of $1.0 \mathrm{~kg} \cdot \mathrm{ha}^{-1}$.

The potato was grown in the place after the winter cereals. In the experiment the solid organic fertilization with manure $25 \mathrm{tha}^{-1}$ and mineral in the quantities: $90 \mathrm{~kg} \mathrm{ha}^{-1} \mathrm{~N}, 32.9 \mathrm{~kg} \mathrm{ha}^{-1} \mathrm{P}$ and $112.1 \mathrm{~kg} \mathrm{ha}^{-1} \mathrm{~K}$ were used. Potatoes were harvested in the phase of technological maturity in the first decade of September. The samples of potato tubers for chemical analyses were taken from the plots during the harvest. In the dry matter of tubers the contents: of total nitrogen was marked with the Kjeltec method on the apparatus of 2300 Kjeltec Analyzer Unit, phosphorus, with the photometric method, while the potassium, with the method of absorption atomic spectrophotometry
(ASA) [Ostrowska et al. 1991]. The determination of values was expressed in $\mathrm{g} \cdot \mathrm{kg}^{-1}$ of the dry mass of tubers.

Test results were developed statistically with the method of the variance analysis. The significance of the sources of variation was tested with the 'F' Fischler-Snedecor test, and the assessment of the significance of differences with the significance level $\mathrm{P}=0.05$ between the compared averages using the multiple Tukey ranges [Trętowski, Wójcik 1991].

Weather conditions in the years when the studies were conducted varied and are presented in Table 1. In 2005 the total rainfall was $268.8 \mathrm{~mm}$ and according to the calculated ratio of Sielianinow the growing season was characterised by the lack of drought, however, there were months of extreme conditions, from strong drought in April and September, to the lack of drought in May and July. The growing season of 2006 was also characterised by the lack of drought. Rainfall was the biggest and were higher than the average sum of the multi-year, however, they were unevenly distributed. The lowest was recorded in the months of June and July determining the development, yielding and accumulation of ingredients of the potato tubers. While the most favourable for the potato growing season was 2007, in which the rainfall was $308.2 \mathrm{~mm}$. According to the hydrothermal coefficient, weather conditions in particular months were varied, however, evenly distributed.

Table 1. Weather conditions in potato growing season in the years 2005-2007

\begin{tabular}{|c|c|c|c|c|c|c|c|}
\hline \multirow{2}{*}{ Years } & \multicolumn{7}{|c|}{ Months } \\
\hline & IV & V & VI & VII & VIII & IX & IV-IX \\
\hline \multicolumn{7}{|c|}{ Rainfalls (mm) } & Sum \\
\hline 2005 & 12.3 & 64.7 & 39.6 & 86.5 & 45.4 & 15.8 & 268.8 \\
\hline 2006 & 29.8 & 59.1 & 44.1 & 16.2 & 228.1 & 20.9 & 358.6 \\
\hline 2007 & 21.2 & 24.0 & 59.0 & 70.2 & 31.1 & 67.6 & 308.2 \\
\hline Multiyear sum (1981-1995) & 52.3 & 50.0 & 68.2 & 45.7 & 66.8 & 60.7 & 343.7 \\
\hline \multicolumn{7}{|c|}{ Air temperature $\left({ }^{\circ} \mathrm{C}\right)$} & Mean \\
\hline 2005 & 8.7 & 13.0 & 15.9 & 20.2 & 17.5 & 15.0 & 15.0 \\
\hline 2006 & 8.4 & 13.6 & 17.2 & 22.3 & 18.0 & 15.4 & 15.8 \\
\hline 2017 & 8.6 & 14.6 & 18.2 & 18.9 & 19.9 & 13.1 & 15.4 \\
\hline Multiyear mean (1987-2000) & 7.7 & 10.0 & 16.1 & 19.3 & 18.0 & 13.0 & 14.0 \\
\hline \multicolumn{8}{|c|}{ Sielianinovs hydrothermic coefficients } \\
\hline 2005 & 0.47 & 1.60 & 0.92 & 1.51 & 0.84 & 0.35 & 1.00 \\
\hline 2006 & 1.18 & 0.99 & 0.47 & 0.24 & 4.18 & 0.45 & 1.26 \\
\hline 2007 & 0.82 & 1.37 & 1.08 & 1.23 & 0.53 & 1.72 & 1.10 \\
\hline
\end{tabular}

Value of coefficients Sielianinovs: $<0.5$ strong mild drought, $0.51-0.69$ mild, $0.70-0.99$ weak mild drought, $\geq 1$ fault mild drought. 


\section{RESULTS AND DISCUSSION}

The obtained results showed that the total nitrogen content in potato tubers were affected by the varieties grown in the experiment, ways of care, and the weather conditions in different years of studies.

According to Kołodziejczyk et al. [2010], Marks et al. [2005], Wichrowska et al. [2009] and Wierzbicka, Trawczyński [2012] the content of nitrogen, and thus protein in potato tubers is shaped by the genetic characteristics of varieties, which was confirmed in own studies, which showed that a significantly higher total nitrogen content - an average of $15.84 \mathrm{~g} \cdot \mathrm{kg}^{-1}$ was obtained by growing the Irga variety, while the Balbina variety was characterised by a lower content of the discussed component - an average of $14.58 \mathrm{~g} \cdot \mathrm{kg}^{-1}$ (Table 2).

The mechanical care using herbicides applied in the experiment had a significant effect on the growth of the total nitrogen content in potato tubers (Table 2). The highest concentration of the element was stated on object 3 , where the single soiling was used and up to 10 days after planting potatoes spraying with herbicide Racer $250 \mathrm{EC}$ at a dose of $3.0 \mathrm{dm}^{3} \cdot \mathrm{ha}^{-1}$. High content of total nitrogen was also obtained on object 4 , where the mechanical care was used with herbicide Sencor $70 \mathrm{WG}$ at a dose of $1,0 \mathrm{~kg} \cdot \mathrm{ha}^{-1}$. The average contents of the discussed component in potato tubers were respectively -15.32 $\mathrm{g} \cdot \mathrm{kg}^{-1}$ and $15.26 \mathrm{~g} \cdot \mathrm{kg}^{-1}$. Also Wichrowska et al. [2009] found that the plant protection products have a positive effect on the total nitrogen content in potato tubers causing it to grow. While Pszczółkowski, Sawicka [2009] demonstrated that the care using herbicides caused the reduction of the total protein contents in tubers or did not differentiate the value of this feature in comparison to the mechanical care.

Grzebisz [2011] thinks that one of the reasons of the insufficient demand with macronutrients is that the modern varieties highly yielding are poorer in terms of minerals than the old, low yielding ones. The statistical analysis revealed significant differences of phosphorus contents in potato tubers (Table 3). The Irga variety was characterised by a greater concentration of phosphorus - an average of $3.526 \mathrm{~g} \cdot \mathrm{kg}^{-1}$.

The applied care treatments using herbicides contributed to the reduction of concentration of this macro element (on average from 0.038 to $0.073 \mathrm{~g} \cdot \mathrm{kg}^{-1}$ ) in comparison to potatoes collected from the control object (Table 3), however, these differences were not statistically significant. These results were confirmed in the previous studies of Zarzecka, Gugała [2010], who demonstrated that the herbicides used in the care impacted the reduction of the phosphorus content compared to the tubers from the control object. While Wichrowska et al. [2009] found that the tubers harvested from objects sprayed with herbicides contained $8.1 \%$ less phosphorus than the tubers only under the mechanical care.

According to Miles, Buchman [2009], White et al. [2009], Wichrowska et al. [2009], Wierzbicka, Trawczyński [2011] the potassium content in potato tubers is shaped by the genetic properties of the varieties. The results of own studies showed that from among the cultivated varieties (Table 4) significantly higher potassium content was found in the Balbina variety - on average $25.28 \mathrm{~g} \cdot \mathrm{kg}^{-1}$ while the lower one characterised the Irga variety (23.63 $\left.\mathrm{g} \cdot \mathrm{kg}^{-1}\right)$. In contrast, Wadas et al. [2007] cultivating early varieties of potato stated a similar potassium content, and differences were not significant.

Table 2. Content of total nitrogen in potato tubers $\left(\mathrm{g} \cdot \mathrm{kg}^{-1}\right.$ dry matter)

\begin{tabular}{|c|c|c|c|c|c|c|}
\hline \multirow{2}{*}{ Weed control methods } & \multicolumn{2}{|c|}{ Cultivars } & \multicolumn{3}{|c|}{ Years } & \multirow{2}{*}{ Mean } \\
\hline & Irga & Balbina & 2005 & 2006 & 2007 & \\
\hline 1. Control & 15.71 & 14.48 & 15.35 & 14.25 & 15.71 & 15.10 \\
\hline 2. Plateen 41,5 WG & 15.77 & 14.56 & 15.46 & 14.30 & 15.75 & 15.17 \\
\hline 3. Racer $250 \mathrm{EC}$ & 15.98 & 14.66 & 15.55 & 14.63 & 15.80 & 15.32 \\
\hline 4. Sencor 70WG & 15.88 & 14.63 & 15.47 & 14.53 & 15.77 & 15.26 \\
\hline Mean & 15.84 & 14.58 & 15.46 & 14.43 & 15.76 & - \\
\hline $\begin{array}{l}\text { LSD }_{0.05} \text { for: } \\
\text { - years } \\
\text { - cultivars } \\
\text { - weed control methods } \\
\text { Interaction: } \\
\text { - years } \times \text { cultivars }\end{array}$ & & & & & & $\begin{array}{l}0.18 \\
0.12 \\
0.11 \\
\\
0.21\end{array}$ \\
\hline
\end{tabular}


Table 3. Content of phosphorus in potato tubers $\left(\mathrm{g} \cdot \mathrm{kg}^{-1}\right.$ dry matter)

\begin{tabular}{|l|c|c|c|c|c|c|}
\hline \multirow{2}{*}{ Weed control methods } & \multicolumn{2}{|c|}{ Cultivars } & \multicolumn{2}{c|}{ Years } & \multirow{2}{*}{ Mean } \\
\cline { 2 - 7 } & Irga & Balbina & 2005 & 2006 & 2007 & 3.535 \\
\hline 1. Control & 3.586 & 3.484 & 3.513 & 3.575 & 3.518 & 3.482 \\
\hline 2. Plateen 41,5 WG & 3.501 & 3.462 & 3.465 & 3.500 & 3.480 & 3.497 \\
\hline 3. Racer 250 EC & 3.523 & 3.470 & 3.490 & 3.510 & 3.490 & 3.462 \\
\hline 4. Sencor 70WG & 3.494 & 3.430 & 3.450 & 3.477 & 3.460 & - \\
\hline \multicolumn{1}{|c|}{ Mean } & 3.526 & 3.462 & 3.480 & 3.516 & 3.487 & 0.060 \\
\hline LSD $_{0.05}$ for cultivars & \multicolumn{7}{|l}{} \\
\hline
\end{tabular}

Table 4. Content of potassium in potato tubers $\left(\mathrm{g} \cdot \mathrm{kg}^{-1} \mathrm{dry}\right.$ matter)

\begin{tabular}{|c|c|c|c|c|c|c|}
\hline \multirow{2}{*}{ Weed control methods } & \multicolumn{2}{|c|}{ Cultivars } & \multicolumn{3}{|c|}{ Years } & \multirow{2}{*}{ Mean } \\
\hline & Irga & Balbina & 2005 & 2006 & 2007 & \\
\hline 1. Obiekt kontrolny & 23.83 & 25.54 & 25.04 & 23.74 & 25.28 & 24.69 \\
\hline 2. Plateen $41,5 \mathrm{WG}$ & 23.50 & 25.16 & 24.82 & 23.14 & 25.04 & 24.33 \\
\hline 3. Racer $250 \mathrm{EC}$ & 23.68 & 25.23 & 24.97 & 23.22 & 25.18 & 24.46 \\
\hline 4. Sencor 70WG & 23.50 & 25.18 & 24.88 & 23.04 & 25.11 & 24.34 \\
\hline Mean & 23.63 & 25.28 & 24.93 & 23.29 & 25.15 & - \\
\hline $\begin{array}{l}\mathrm{LSD}_{0.05} \text { for: } \\
\text { - years } \\
\text { - cultivars } \\
\text { Interaction: } \\
\text { - years } \times \text { cultivars }\end{array}$ & & & & & & $\begin{array}{l}0.27 \\
0.17 \\
0.30\end{array}$ \\
\hline
\end{tabular}

Herbicides used in the experiment did not have a significant effect on the potassium content, however, they caused a slight reduction of the content of this component - an average of 0.23 to $0.36 \mathrm{~g} \cdot \mathrm{kg}^{-1}$ in relation to the control object. These results were confirmed in the studies of Klikocka [2001] and Zarzecka, Gugała [2004], who observed the tendency to reduce the potassium content in tubers due to the use of herbicides. While Dobozi et al. [2003] and Wichrowska et al. [2009] showed an increase of potassium in potato tubers after the use of herbicides.

The effect of weather conditions during the growing season on the protein content in potato tubers is also reported by Lachman et al. [2005], Zrủst, Hola [1994]. Analysing the effect of weather conditions on the concentration of total nitrogen in potato tubers in own studies it was found that the greatest content of this element $\left(15.76 \mathrm{~g} \mathrm{~kg}^{-1}\right)$ was noted in 2007, which was characterised by the average content of rainfall and the average air temperature during the growing season (Table 2). However, the significantly lowest content of the discussed component characterised the tubers harvested in the year with the greatest rainfall and the greatest average air temperature. Also Marks et al. [2005] obtained the lowest amount of pro- tein in the year with the greatest rainfall. Statistical calculations have shown that the potassium content in edible potato tubers was significantly influenced by weather conditions during the studies (Table 4). The largest amounts of potassium were in tubers collected in 2007, which was characterised in a three-year research cycle with rainfall and temperatures at the average level. These results were confirmed in the studies of Klikocka [2001], who proved that in the year with lower rainfall, there was $2 \%$ more potassium than in a wet year. While Wierzbicka, Trawczyński [2011] found that in a year with high rainfall the potassium content was the highest, and in a year marked by a deficit the rainfall was the lowest.

The analysis of variance did not show any significant influence of weather conditions on the phosphorus content in edible potato tubers.

\section{CONCLUSIONS}

1. Herbicides used in the experiment influenced the increase of the total nitrogen content from 0.07 to $0.22 \mathrm{~g} \cdot \mathrm{kg}^{-1}$ of the dry mass of tubers and reduction of the potassium content by 0.23 to $0.36 \mathrm{~g} \cdot \mathrm{kg}^{-1}$ compared to the control object. 
2. The studied varieties were significantly different in terms of the contents of the discussed components. The Irga variety showed a higher concentration of total nitrogen and phosphorus 15.84 and $3.526 \mathrm{~g} \cdot \mathrm{kg}^{-1}$ respectively, and the Balbina variety of potassium $25,28 \mathrm{~g} \cdot \mathrm{kg}^{-1}$.

3. Changing weather conditions in particular years of studies has a significant impact on the content of total nitrogen and potassium, while they did not have a significant effect on the concentration of phosphorus.

\section{REFERENCES}

1. Dobozi M., Lehoczky E., Horváth S. 2003. Investigation of the effect of soil herbicides on the growth and nutrient uptake of potato. Commun. Agric. Appl. Biol. Sci., 68(4), 441-447.

2. Grzebisz W. 2011. Magnesium - ford and human health. J. Elementol., 16(2), 299-323.

3. Gugała M., Zarzecka K., Mystkowska I. 2009. The influence of herbicides on selected qualitative traits in potato. Prog. Plant Prot./Post. Ochr. Roślin, 49(1), 436-439.

4. Klikocka H. 2001. Wpływ stosowania różnych sposobów uprawy roli i pielęgnowania ziemniaków na zawartość makroelementów w ich bulwach (The effect of using different ways of cultivation and care of potatoes on the content of macronutrients in their tubers). Biul. IHAR, 217, 197-203.

5. Kołodziejczyk M., Ropek D., Szmigiel A. 2010. Formation of potato leaf area and chemical composition of tubers in depending on colorado potato beetle control methods. Prog. Plant Protection/ Post. Ochr. Roślin, 50(1), 477-481.

6. Lachman J., Hamouz K., Dvořák P., Orsák M. 2005. The effect of selected factors on the content of protein and nitrates in potato tubers. Plant Soil Environ., 10, 431-438.

7. Marks N., Krzysztofik B., Szmigiel A. 2005. Connection between the content of nitrogen compound in potato tubers and their susceptibility to mechanical damage. Inż. Roln., 4(64), 7-14.

8. Miles G.P., Buchman J.L. 2009. Impact of zebra chip disease on the mineral content of potato tu- bers. Am. J. Potato Res.,86, 481-489.

9. Ostrowska A., Gawliński S., Szczubiałkowa Z. 1991. The method of analysis and the opinion of propriety of soils and the plants. Inst. Ochr. Środ., Warszawa, pp. 55.

10. Pszczółkowski P., Sawicka B. 2009. The content of protein and nitrite in tubers of very early varieties of potato grown under protection (in Polish). Zesz. Probl. Post. Nauk Rol., 542, 413-426.

11. Stefańska E., Karczewski J., Ostrowska L., Czapska D. 2003. The content of magnesium and zinc in the daily diet of students of the Medical University in Bialystok (in Polish). J. Elementol., 8(1), 31-39.

12. Trętowski J., Wójcik R. 1991. Metodyka doświadczeń rolniczych (Methodology of agricultural experiments). Wyd. WSRP Siedlce, pp. 500.

13. Wadas W., Jabłońska-Ceglarek R., Kosterna E., Łęczycka T. 2007. The potassium content in early potato tubers depending on cultivation method. Roczn. AR w Poznaniu, Ogrodn., 41, 643-647.

14. White P.J. Bradshaw J.E., Finaly M., Dale B., Ramsay G., Hammond J.P., Broadley M.R. 2009. Relationships between yield and mineral concentrations in potato tubers. Hort. Sci., 44(1), 6-11.

15. Wichrowska D., Wojdyła T., Rogozińska I. 2009. Concentrations of some macroelements in potato tubers stored at $4^{\circ} \mathrm{C}$ and $8^{\circ} \mathrm{C}$. J. Elementol., 9(2), 373-382.

16. Wierzbicka A., Trawczyński C. 2011. Effect of irrigation and soil's microorganisms on the macro and micronutrient contents in organic potato tubers. Fragm. Agron., 28(4), 139-148.

17. Wierzbicka A., Trawczyński C. 2012. Factors affecting the content and yield of protein in potato tubers (in Polish). Biul. IHAR, 266, 181-190.

18. Zarzecka K., Gugała M. 2004. Phosphor and potassium contents in edible potato bulbs depending on the ways of weeds control. Hortic. Vegetable Growing, 23(3), 128-135.

19. Zarzecka K., Gugała M. 2010. Content and uptake of phosphorus and calcium with the yield of potato tubers depending on cultivation operations. J. Elementol., 15(2), 385-392.

20. Zrůst J., Hola Z. 1994. Vliv prechodného obdobi sucha na obsah celkoveho a bilkovinného dusicku a dusičnanů v hlizach brambor. Rostl. Vyroba, 40, 271-279. 